\title{
Oxidation Products of Nitric Oxide and the Concentrations of Antioxidant Vitamins in Parasitized Goats
}

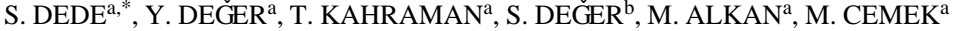 \\ ${ }^{a}$ Department of Biochemistry, ${ }^{b}$ Department of Parasitology,Faculty of Veterinary Medicine, Yuzuncu Y1l \\ University, Van, Turkey
}

Received August 15, 2001

Accepted May 8, 2002

Abstract

Dede S., Y. Değer, T. Kahraman, S. Değer, M. Alkan, M. Cemek: Oxidation Products of Nitric Oxide and the Concentrations of Antioxidant Vitamins in Paarasitized Goats. Acta Vet. Brno 2002, 71: 341-345.

The status of nitric oxide oxidation products and antioxidant vitamins were investigated in goats infected with endoparasites and blood parasites (Trichostrongylidae sp. + Protostrongylidae sp. + Eimeria sp. + Babesia sp.), in this study. Eighteen goats were naturally infected with these parasites and ten healthy goats served as controls which had been treated with antiparasitic drugs after parasitological examinations were carried out. The concentrations of nitric oxide oxidation products (nitrate, nitrite) and antioxidant vitamins (vitamins E and C, $\beta$-carotene and retinol) were determined spectrophotometrically in the blood serum of all goats. The results were expressed as nitrate $(\mu \mathrm{g} / \mathrm{ml}) 7.25 \pm 1.31-4.69 \pm 0.32 ;$ nitrite $(\mu \mathrm{g} / \mathrm{ml}) 1.52 \pm 0.39-1.64 \pm 0.19 ;$ vitamin $\mathrm{E}(\mathrm{mg} / 100)$ $0.13 \pm 0.05-0.42 \pm 0.02$; vitamin C (mg/100 ml) $1.49 \pm 0.26-1.46 \pm 0.15$; retinol $(\mathrm{g} / 100 \mathrm{ml}) 201.51$ $\pm 15.69-234.081 \pm 45.15 ; \beta$-carotene $(\mathrm{g} / 100 \mathrm{ml}) 62.71 \pm 7.14-53.95 \pm 3.82$. In conclusion, nitrate concentrations of the infected group were higher than controls $(p<0.05)$ whereas vitamin E levels of the infected group were lower than the control group $(p<0.05)$. The concentrations of the other indices examined were not statistically different between groups. These results suggest that the parasitic infections have direct effects on the concentrations of vitamin E, an important antioxidant, and on the increase of nitrate levels which may result from the pathophysiological effects of the parasitic infections.

Goat, parasite, nitrate, nitrite, antioxidant vitamins

There are important changes in the biochemistry of hosts suffering from parasitic invasions depending on the species of the parasites and the sites of the hosts they invade (Aksakal and Özer 1987; Özer et al. 1995; Russel and Mc Dowell 1989). Gastrointestinal parasites in goats cause anemia by decreasing the amount of haemoglobin (Hb) and the numbers of erythrocytes (Deger 1990; Özer et al. 1995). Intra-erythrocytic parasites (Babesia, Plasmodium) metabolise $\mathrm{Hb}$. As a result, the free $\mathrm{O}_{2}$ and $\mathrm{H}_{2} \mathrm{O}_{2}$ increase lipid peroxidation (Deger 1990; Ginsburg and Atamina 1994).

$\mathrm{NO}$ is a biologic mediator in biochemical reactions, and physiologically, it is synthesised from L-arginine by NO synthase employing cofactor NADPH. In the host the levels of NO arise in some pathologic situations. In the body the $\mathrm{NO}$ is oxidised to $\mathrm{NO}_{2}$ and $\mathrm{NO}_{3}$ within a very short period of time. This short duration in the conversion of $\mathrm{NO}$ to $\mathrm{NO}_{2}$ and $\mathrm{NO}_{3}$ makes it difficult to accurately measure the concentration of NO. Therefore, by determining the amounts of $\mathrm{NO}_{2}$ and $\mathrm{NO}_{3}$ the levels of $\mathrm{NO}$ can be assessed (Bredt and Snyder 1994; Moncada et al. 1991; Torreilles and Guÿerin 1995).

Anti-oxidant vitamins such as E, C, and A protect the cells from damage against free oxygen radicals generated as a result of parasitoses (Chuenkova et al. 1989; Medzyavichyus et al. 1989). Vitamins A, C, E, thiamin, riboflavin, pantothenic acid,

Address for correspondence:

Dr. Semiha Dede

Department of Biochemistry

Yuzuncu Yll University, Van, Turkey
Phone: +904322221818

Fax : +904322251127

http://www.vfu.cz/acta-vet/actavet.htm 
biotin, and folic acid have a protective role on the liver (Russel and Mc Dowell 1989).

This study investigated the NO products and the levels of antioxidant vitamins in goats infected with parasites (Trichostrongylidae $\mathrm{sp}+$ Protostrongylidae $\mathrm{sp}+$ Eimeria $\mathrm{sp}+$ Babesia sp).

\section{Materials and Methods}

Hair goats $(n=28)$ that were used for the experiment had a body mass of $25-30 \mathrm{~kg}$ and age of 3-4 years. The animals were maintained in a controlled environment (paddock) that mimicked their natural habitat. Faecal samples obtained from animals under study were analysed for helmith eggs and larvae, and cysts and oocysts of protozoa by sedimentation and saturated salt solution of Fulleborn (Celikkol 1995) and flotation by Baermann's technique, and blood was obtained from the ears and was examined for blood protozoa in haematological slides (Celikkol 1995). In addition, in the faeces of the infected group, eggs and oocysts were counted by the method of McMaster (Celikkol 1995). According to the analysis of the faeces, 18 goats were found to be infected with a mixture of (Trichostrongylidae $\mathrm{sp}+$ Protostrongylidae $\mathrm{sp}+$ Eimeria $\mathrm{sp}+$ Babesia $\mathrm{sp}$.$) , other ten goats were parasite free.$ They were treated with anti-helminthic agents (Rafoxanide + Albendazole + Sulfamezatin) twice, at a one-week long interval against any parasitic contamination. Fifteen days following the last treatment, the goats were examined using the same methods as above. These animals were used as controls after it was demonstrated that they were free of parasites. Sera were obtained from both groups after bleeding the animals as previously. The blood samples of control group were collected after last exam that has shown the goats are parasite free. The concentrations of oxidation products of serum NO were determined by coupling reagent (Sthar 1977). Analysis of vitamin C were made by employing the methods of Omaye et al. (1979), vitamin E by Martinek (1964), and $\beta$-carotene and retinol by Suzuki and Katoh (1990). The results of the experimental findings were analysed statistically using Duncan's tests.

\section{Results}

Eggs of Trichostrongylidae sp were detected by flotation, oocysts of Eimeria and larvae of Protostrongylidae sp were found by Baermann's technique. Babesia sp were found in the blood samples obtained from the ears or tails. The outcome of the sedimentation experiments was negative for helminth eggs. By employing the method of McMaster, the egg numbers of Trichostrongylidae sp were 6400/g, and the oocysts of Eimeria sp were 4800/g.

Table 1

Concentrations of oxidation products of $\mathrm{NO}$ and antioxidant vitamins in the sera of goats infected with parasites (mean $\pm \mathrm{SD}$ )

\begin{tabular}{|c|c|c|}
\hline Parameters & Patients $(\mathrm{n}=18)$ & Controls $(\mathrm{n}=10)$ \\
\hline & Mean \pm SD & Mean \pm SD \\
\hline Nitrate $(\mu \mathrm{g} / \mathrm{ml})$ & $7.25 \pm 1.31 *$ & $4.69 \pm 0.32$ \\
\hline Nitrite $(\mu \mathrm{g} / \mathrm{ml})$ & $1.52 \pm 0.39$ & $1.64 \pm 0.19$ \\
\hline
\end{tabular}

$* p<0.05$

Table 2

Concentrations of antioxidant products vitamins in the sera of goats infected with parasites (mean \pm SD)

\begin{tabular}{|c|c|c|}
\hline Parameters & Patients $(\mathrm{n}=18)$ & Controls $(\mathrm{n}=10)$ \\
\hline Vitamin E $(\mathrm{mg} / 100 \mathrm{ml})$ & $0.13 \pm 0.05^{*}$ & $0.42 \pm 0.02$ \\
\hline Vitamin C $(\mathrm{mg} / 100 \mathrm{ml})$ & $1.49 \pm 0.26$ & $1.46 \pm 0.15$ \\
\hline Retinol $(\mathrm{g} / 100 \mathrm{ml})$ & $201.51 \pm 15.69$ & $234.08 \pm 45.15$ \\
\hline$\beta$-carotene $(\mathrm{g} / 100 \mathrm{ml})$ & $62.71 \pm 7.14$ & $53.95 \pm 3.82$ \\
\hline
\end{tabular}

$* p<0.05$ 
The biochemical findings obtained after the study are summarised in Tables 1 and 2 .

The results of statistical analysis showed that in the infected group the concentrations of nitrate, as evaluated by Duncan's test, increased significantly $(p<0.05)$ while the levels of vitamin $\mathrm{E}$ decreased $(p<0.05)$. There was no significant change in the levels of nitrite, retinol, $\beta$-carotene and vitamin $\mathrm{C}$ in any group.

\section{Discussion}

In a number of studies, it has been demonstrated that in the cells of hosts infected with different species of parasites, the amount of reactive oxygen radicals which cause lipid peroxidation are increased, thereby causing cell and tissue damage (Sarin et al. 1993; Smith and Bryant 1989; Stocker et al. 1986). Intra-erythrocytic parasites metabolise haemoglobin and produce $\mathrm{O}_{2}$ which causes oxidative stress (Ginsburg and Atamina 1994; Mis hra et al. 1994). In addition, it has been reported that endoparasites like Fasciola, Trichostrongylus and Eimeria cause lipid peroxidation (Dede et al. 2000).

It has been widely reported that the concentration of NO synthesized physiologically increases in some pathologic circumstances, and it acts as a free radical (Bredt and Sny der 1994; Moncada et al. 1991; Torreilles and Guÿerin 1995). In this study, it was demonstrated that the concentration of nitrate increased significantly in goats infected with parasites $(p<0.05)$. In experimental leishmaniosis in rats, Bories et al. (1997) demonstrated that there was an increase in serum nitrate levels. They point out that elevated serum nitrate concentrations can be used as differential diagnostic criteria in the follow up of patients with visceral Leishmaniosis.

Antioxidant systems comprising vitamins have a cellular protective action against oxidative stress resulting in cell, organ and tissue damage as a result of parasitic invasion (Dede et al. 2000; Mishra et al. 1994; S mith and Bryant 1989). Das et al. (1994) have proposed that, since parasites damage the cells which synthesise the molecules carrying the anti-oxidative agents, a decrease in the numbers of such cells is natural. Babesia sp. cause oxidative degeneration in erythrocytes while Eimeria sp. cause epithelial lesions. Gastrointestinal worms like Trichostrongylidae sp cause damage in the cellular lining of gastrointestinal tissue, and pulmonary worms like Protostrongylidae sp. damage the cells of the lung tissue (Aksakal and Özer 1987; Awadalla et al. 1993; Das et al. 1994; Dede et al. 1997; Dede et al. 2000; Ginsburg and Atamina 1994; Mishra et al. 1994).

In this study the levels of serum vitamin $E$ were found to be significantly lower in the infected group $(p<0.05)$ than in the control group. Sarin et al. (1993) found that in hosts infected with different parasites the concentrations of vitamin E fell in comparison to healthy controls, thus supporting the findings of this study.

It has been reported that serum vitamin C levels decline in sheep infected with Fasciola sp (Gameel 1982) and Trichostrongylidae sp. (Dede et al. 1997) while infections with Plasmodium sp. result in the opposite situation (Sarin et al. 1993; Stocker et al. 1986). In addition, a decrease in the concentration of vitamin A in animals infected with parasites has been reported (Awadalla et al. 1993; Das et al. 1994; Hautvast et al.1998). However, in this study no significant differences were found in the concentrations of retinol and its precursor $\beta$-carotene between the infected and control groups. These findings indicate that the concentrations of vitamins $\mathrm{A}$ and $\mathrm{C}$ are affected by the types of parasites and the hosts they invade.

It is concluded that the elevated levels of nitrate concentrations in serum of goats infected with parasites is a result of damage caused by the invasion. While there was a significant decrease in the concentration of vitamin $\mathrm{E}$, there were no significant changes in the concentrations of other anti-oxidant vitamins (vitamin $\mathrm{C}, \beta$-carotene and retinol) which are responsible for protecting the cells from damage caused by lipid peroxidation. It is proposed that variations in the concentrations of these vitamins is dictated by the types of the parasites and hosts they invade. 


\section{Stanovení oxidačních produktů oxidu dusičného a koncentrace antioxidačních vitamínů u koz s parazitárními nákazami}

V této studii byla stanovena koncentrace oxidačních produktů oxidu dusičného a antioxidačních vitamínů u koz infikovaných endoparazity a krevními parazity (Trichostrongylidae sp. + Protostrongylidae sp. + Eimeria sp. + Babesia sp.). U osmnácti koz přirozeně infikovaných těmito parazity a deseti zdravých koz sloužících jako kontrola bylo po léčbě antiparazitikem. Koncentrace oxidačních produktů oxidu dusičného (dusičnany, dusitany) a antioxidačních vitamínů (vitamín E a C, -karoten a retinol) byla stanovena spektrofotometricky v krevním séru koz. Výsledky byly vyjádřeny jako dusičnan $(\mu \mathrm{g} / \mathrm{ml}) 7.25 \pm 1.31-4.69 \pm 0.32$; dusitan $(\mu \mathrm{g} / \mathrm{ml}) 1.52 \pm 0.39-1.64 \pm 0.19$; vitamin $\mathrm{E}(\mathrm{mg} / 100) 0.13 \pm 0.05-0.42 \pm 0.02$; vitamin $\mathrm{C}(\mathrm{mg} / 100 \mathrm{ml}) 1.49 \pm 0.26-1.46 \pm 0.15$; retinol $(\mathrm{g} / 100 \mathrm{ml}) 201.51 \pm 15.69-234.081 \pm 45.15 ; \beta$-caroten $(\mathrm{g} / 100 \mathrm{ml}) 62.71 \pm 7.14-53.95 \pm 3.82$. Koncentrace dusičnanů byla u infikované skupiny vyšší $(p<0.05)$, zatímco obsah vitamínu E byl nižší než u skupiny kontrolní $(p<0.05)$. Koncentrace ostatních stanovovaných ukazatelů se mezi skupinami statisticky nelišila. Tyto výsledky naznačují, že parazitární infekce má př́imý vliv na koncentraci vitaminu E, důležitého antioxidantu, a zvýšení obsahu dusičnanů, což může být výsledkem patofysiologických vlivů parazitární infekce.

\section{References}

AKSAKAL, M, ÖZER, E 1987: Investigations on hematological values and vitamin E levels of sera before and after treatment with antihelmentic drugs in Akkarman sheep. A Ü Vet Fak Derg 34: 72-84

AWADALLA, SF, SALEM, HAH, AWADALLA, SA 1993: Effect of Ascaridia galli infestation on body weight, vitamin A and some blood constituents in chicken. Vet Med J Giza 41: 41-45

BORIES, C, SCHERMAN, E, BORIES, PN 1997: Serum and tissue nitrate levels in murine visceral leishmaniasis correlate with parasite load but not with host protection. Trans R Soc Trop Med Hyg 91: 433-436

BREDT, DS, SNYDER, SH 1994: Nitric oxide, a physiological messenger molecule. Ann Rev Biochem 63: 175195

CELIKKOL, G 1995: The Main Techniques and Diagnosis Methods in Parasitology. MSc Thesis, Institute of Health Sciences, University of Yuzuncu Yil, Van.

CHUENKOVA, MV, SUKHAREVA, NN, SERGACHEVA, YY, SOKHANENKOVA, TL, SOPRUNOV, FF, GRINBERG, LG 1989: The effect of vitamin E on the lipid composition in mouse erythrocytes and in Plasmodium berghei. Protozool Abst 013-01808

DAS, BS, THURNHAM, DI, DAS, DB 1994: Plasma alpha-tocopherol, retinol, and carotenoids in children with Falciparum malaria. Am J Clin Nutr 64: 94-100

DEDE, S, BILDIK, A, DEGER, S, DEGER, Y, YUR, F, 1997: Plasma vitamin C and ceruloplasmin levels in the sheep infected with Trichostrongylosis. Acta Paras Turc 21:191-194.

DEDE, S, DEGER, Y, DEGER, S, ALKAN, M, 2000: Determination of the status of lipid peroxidation and antioxidants in sheep infected with certain endoparasites (Fasciola sp, Trichostrongylidae sp., Eimeria sp,). Acta Paras Turc 24: 190-193

DEGER, S, 1990: Studies on Seroepidemiology of Babesisosis of Sheep in Van Province. PhD Thesis, Institute of Health Sciences, University of Ankara, Ankara.

GAMEEL, AA, 1982: Fasciola hepatica: plasma ascorbic acid, plasma iron and iron-binding capacity in experimentally infected sheep. Z Parasitenkde 68: 185-189

GINSBURG, H, ATAMINA, H, 1994: The redox status of malaria-infected erythrocytes: an overview with an emphasis on unresolved problems. Parasite 18: 5-13

HAUTVAST, JL, TOLBOOM, JJ, WEST, CE, KAFWEMBE, EM, SAUERWEIN, RW, VAN STAVEREN, WA 1998: Malaria is associated with reduced serum retinol levels in rural Zambian children. Int J Vitam Nutr Res 68: $384-388$

MARTINEK, R 1964: Method for determination of vitamin E (total tocopherol) in serum. Clin Chem 10: 10781086

MEDZYAVICHYUS, AK, BEBRAVICHYUS, VY, DREBITSKENE, GA, MOZALENE, EE, MEDZEVICIUS, A, BEBRAVICIUS, V, DREBICKIENE, G, MOZALIENE, E 1989: Effect of vitamin A and C on immunity to Trichuriasis in piglets under industrial farming conditions. Acta Parasitol Lit 23: 115-129

MISHRA, NC, KABILAN, L, SHARMA, A 1994: Oxidative stress and malaria-infected erythrocytes. Ind J Malariol 31: 77-87

MONCADA, S, PALMER, RMJ, HIGGS, EA 1991. Nitric Oxide: physiology, pathophysiology, and pharmacology. Pharmacol Rev 43: 109-142 
OMAYE, ST, TURNBUL, JD, SAVBERLICH, HE 1979: Ascorbic acid analysis. II. Determination after derivatisation with 2.2. dinitrophenylhydrazine. Selected methods for determination of ascorbic acid in animal cells, tissues and fluids. Methods in Enzymology, London, 62, $7 \mathrm{p}$.

ÖZER, E, YILMAZ, K, ERKAL, N, SAKI, CE, TURAN, T, ANGIN, M, ÖZTÜRK, G 1995: Iron and iron-binding capacity of male Akkaraman sheep experimentally infected with certain Eimeria sp. FÜ Sag Bil Ens Derg 9: 245-257

RUSSEL, L, MC DOWELL, J 1989: Vitamins in Animal Nutrition, Academic Press Inc., San Diego, California, $92 \mathrm{p}$.

SARIN, K, KUMAR, A, PRAKASH, A, SHARMA, A 1993: Oxidative stress and antioxidant defence mechanism in Plasmodium vivax malaria before and after chloroquin treatment. Ind J Malariol 30: 127-133

SMITH, NC, BRYANT, C 1989: Free radical generation during primary infections with Nippostrongylus brasiliensis. Parasit Immunol 11: 147-160

STHAR, HM 1977: Analytical Toxicology Methods Manual. Iowa State University Press. Ames, Iowa, USA, pp. 68-71

STOCKER, R, HUNT, NH, WIEDEMANN, MJ, 1986: Antioxidants in plasma from mice infected with Plasmodium vinckei. Biochem Biophys Res Commun 134: 152-158

SUZUKI, I, KATOH, N 1990. A simple and cheap methods for measuring serum vitamin A in cattle using spectrophotometer. Jpn J Vet Sci 52: 1281-1283

TORREILLES, J, GUYERIN, MC 1995: Does nitric oxide stress exist? C R Seances Soc Biol Fil 189: 389-400 